\title{
Bone Marrow Cell Recruitment Mediated by Inducible Nitric Oxide Synthase/Stromal Cell-Derived Factor- $1 \alpha$ Signaling Repairs the Acoustically Damaged Cochlear Blood-Labyrinth Barrier
}

\author{
Min Dai, ${ }^{*}$ Yue Yang, ${ }^{*}$ Irina Omelchenko, ${ }^{*}$ \\ Alfred L. Nuttall, ${ }^{\star \dagger}$ Allan Kachelmeier, ${ }^{*}$ \\ Ruijuan Xiu, ${ }^{\ddagger}$ and Xiaorui Shi ${ }^{\star \ddagger}$ \\ From the Oregon Hearing Research Center," Department of \\ Otolaryngology and Head and Neck Surgery, Oregon Health and \\ Science University, Portland, Oregon; the Kresge Hearing Research \\ Institute, ${ }^{\dagger}$ University of Michigan, Ann Arbor, Michigan; and The \\ Institute of Microcirculation, ${ }^{\ddagger}$ Chinese Academy of Medical Sciences \\ and Peking Union Medical College, Beijing, China
}

Using a mouse model with noise-induced cochlear blood-labyrinth-barrier (CBLB) injury, we examined the effects of inducible nitric oxide synthase (iNOS) on the recruitment of bone marrow-derived cells (BMDCs) to the CBLB after acoustic injury. Lethally irradiated C57BL/6J and B6.129P2-Nos $2^{\text {tmiLau }} / \mathrm{J}$ mice were transplanted with GFP $^{+}$-BMDCs from C57B1/ 6-Tg (UBC GFP) mice. Four weeks after transplantation, we assessed the population of $\mathrm{GFP}^{+}$-BMDCs in the CBLB. Only small numbers of $\mathrm{GFP}^{+}-\mathrm{BMDCs}$ were found to infiltrate the area of the CBLB in the control recipient mice. However, robust $\mathrm{GFP}^{+}-\mathrm{BMDC}$ migration occurred in the area of the CBLB within the injured cochlea during the first week following acoustic trauma, and further BMDC accumulation was seen by 2 weeks posttrauma. After 4 weeks, the BMDCs were integrated into vessels. Local iNOS from perivascular resident macrophages was found to be important for BMDC infiltration, since mice deficient in iNOS $\left(\operatorname{Inos}^{-1-}\right)$ and mice with iNOS that had been inhibited by $1400 \mathrm{~W}$ displayed reduced BMDC infiltration. Stromal cell-derived factor-1 $\alpha$ (SDF-1 $\alpha)$ and its chemokine receptor 4 (CXCR4) were required for the iNOS-triggered recruitment. BMDC recruitment was significantly reduced by the inhibition of SDF-1 $\alpha$ activity. Inhibition of the iNOS/SDF-1 $\alpha$ signaling pathway reduced vascular repair as observed by reduced vascular density. Our study revealed an intrinsic signaling pathway of iNOS that mediates SDF-1 $\alpha$ to pro- mote GFP $^{+}$-BMDC infiltration/targeting in cochlear vascular repair. (Am J Pathol 2010, 177:3089-3099; DOI: 10.2353/ajpath.2010.100340)

Ischemia causes considerable morbidity in various organ systems, and the pervasiveness of ischemic damage makes repair of damaged vasculature an important therapeutic goal. ${ }^{1}$ Ischemia in the inner ear is closely related to several hearing disorders, including sudden sensorineural hearing loss, presbyacusis, noise-induced hearing loss, tinnitus, and Ménière's disease. ${ }^{2-5}$ Various clinical approaches to treatment of the ischemia have been tried, including use of vasoactive substances to improve cochlear blood flow; however, these generally have not been effective. A fundamental approach to determining the mechanisms of damage repair will enable development of more effective clinical treatments for vascularrelated hearing disorders.

Acoustic trauma not only directly damages sensory hair cells, but it also disrupts the blood flow and the cochlear blood-labyrinth-barrier (CBLB) in the stria vascularis, ${ }^{6}$ creating an ischemic and hypoxic environment. ${ }^{3,6,7}$ Normal blood supply to the cochlea is critical for generating the ionic gradients and the endolymphatic potential required for auditory transduction. 6,8 Better treatment of noise-induced hearing loss requires an understanding of parallel repair factors, one of which will be the cellular repair mechanisms involved in restoration of efficient cochlear blood flow after damage.

Increasing evidence highlights the importance of circulating bone marrow stem cells, which is home to sites

Supported by NIH NIDCD DC DC010844, NIH NIDCD DC 008888-02, NIH NIDCD DC 008888-02S1, NIH NIDCD DC R0100105, and NIH NIDCD DC 005983 (p30)

Accepted for publication July 29, 2010

Address reprint requests to Xiaorui Shi, M.D., Ph.D., Assistant Professor, Oregon Hearing Research Center, Oregon Health and Science University, 3181 SW Sam Jackson Park Rd, NRC04, Portland, OR 97239 E-mail: shix@ohsu.edu. 
of ischemia and contribute to formation of new blood vessels by differentiation. ${ }^{9-11}$ In the context of cancer, inhibition of bone marrow stem cell recruitment to tumors decreases tumor angiogenesis, ${ }^{12}$ whereas the reverse, infusion of bone marrow-derived progenitor cells increases angiogenesis ${ }^{13}$ and improves organ function. For example, transplantation of bone marrow cells into myocardium augments cardiac function following myocardial infarct or chronic ischemia in rats and dogs. ${ }^{14,15}$ Transplantation of bone marrow cells attenuates ischemic damage and improves functional recovery after brain injury. ${ }^{16}$

Coordination of an inflammatory response, entailing regulation of chemokine release, is essential for bone marrow stem cell (BMSC)-associated neovascularization during ischemia and wound healing. ${ }^{17}$ For example, the release of stromal cell-derived factor- $1 \alpha$ (SDF- $1 \alpha$ ) from stressed tissue plays an important role in the mobilization of bone marrow cells to local ischemic sites on damaged vessels. ${ }^{18-20} \mathrm{Ad}$ ditionally, nitric oxide (NO), produced by endothelial nitric oxide synthase (eNOS), is shown to be a critical factor in bone marrow cell recruitment for vascular repair. ${ }^{21}$

Here, we report the finding that recruitment of bone marrow cells to ischemic tissues in the noise traumatized cochlea is signaled by a local inducible nitric oxide synthase (iNOS)-dependent SDF-1 $\alpha$ pathway. Recruitment of bone marrow derived cells (BMDCs) to the damaged stria vascularis results in repair of cochlear vessels.

\section{Materials and Methods}

\section{Animals and Bone Marrow Cell Transplantation}

Male C57BL/6J (Inos wild type [WT], aged 4 weeks; stock number: 000664), B6.129P2-Nos2 ${ }^{\text {tm1Lau/J }}$ (Inos $^{-1-}$, aged 4 weeks; stock number: 002609), and C57BI/6-Tg mice (UBC-GFP, aged 4 to 6 weeks; stock number: 004353) were purchased from Jackson Laboratory (Bar Harbor, $\mathrm{ME})$. C57BI/6-Tg mice served as donor mice with Inos WT, and $I_{n o S^{-I}}$ mice of the same age served as recipients. The recipients were irradiated (at 9 Gy) with a $\gamma$-emitting source and reconstituted with a single periorbital sinus injection of $2 \times 10^{7}$ BMDCs in $200 \mu \mathrm{l}$ of modified HBSS from donor transgenic mice. At 1 month posttransplantation, the mice served as control, noiseexposed, and noise-exposed + drug treatment groups. The groups were sacrificed at different times after noise exposure (immediately, 1 week, 2 weeks, and 4 weeks) for measurement. All procedures in this study were reviewed and approved by the Institutional Animal Care and Use Committee at Oregon Health and Science University.

\section{Noise Exposure}

Animals were placed in wire mesh cages and exposed to broadband noise at $120 \mathrm{~dB}$ sound pressure level (SPL) in a sound exposure booth for 3 hours and for an additional 3 hours the following day. The noise exposure regime, routinely used in our laboratory, produces permanent loss of cochlear sensitivity. ${ }^{6}$

\section{Immunohistochemistry and Fluorescence Microscopy}

Normal and noise-exposed mice were sacrificed at day 2 , week 1 , week 2 , or week 4 , subsequent to a 1 -month transplantation recovery period. The cochleae were harvested and fixed in $4 \%$ paraformaldehyde overnight at $4^{\circ} \mathrm{C}$, and then rinsed in $37^{\circ} \mathrm{C}$ PBS $(\mathrm{pH} \mathrm{7.3)}$ to remove any residual $4 \%$ paraformaldehyde. Immunohistochemistry was performed as described before. ${ }^{6}$ Tissue samples were permeabilized in $0.5 \%$ Triton X-100 (Sigma, St. Louis, MO) for 1 hour, and then immunoblocked with a solution of $10 \%$ goat serum and $1 \%$ bovine albumin in $0.02 \mathrm{~mol} / \mathrm{L}$ PBS for an additional hour. The specimens were incubated overnight at $4^{\circ} \mathrm{C}$ with the primary antibodies (listed in Table 1) diluted in PBS-bovine serum albumin. After several washes in PBS, the samples were incubated with secondary antibodies, Alexa Fluor 568conjugated goat anti-rabbit (category number A21069; Invitrogen, Eugene, OR), Fluor 647-conjugated goat antirabbit (category number A-21244; Invitrogen), and Alexa Fluor 568-conjugated goat anti-rat (category number A-11077; Invitrogen) for 1 hour at room temperature. The tissues were mounted in mounting medium ( $\mathrm{H}-1000$; Vector Laboratories, Inc., Burlingame, CA) and visualized under an FV1000 Olympus laser-scanning confocal microscope (Olympus, Tokyo, Japan). Controls were prepared by replacing primary antibodies with PBS.

\section{Western Blot Analysis}

To investigate the influence of noise exposure on the protein level of iNOS expression, the cochlear lateral wall was dissented from control and noise-exposed animals (cohorts of three mice). The collected lateral wall tissue was homogenized in lysis buffer (RIPA Lysis buffer, Upstate, a Serologicals Company, Temecula, CA) with a protease inhibitor cocktail (Protease Inhibitor cocktails Set III, Calbiochem, Darmstadt, Germany) for 30 seconds. After centrifuging $\left(4^{\circ} \mathrm{C}, 30\right.$ minutes, at 14,000 rpm), the supernatant was assayed for protein by using a DC protein Assay kit (Bio-Rad, Hercules, CA). Samples were heated to $100^{\circ} \mathrm{C}$ for 5 minutes with $2 \times$ SDS loading buffer and briefly cooled on ice. Fifty-microgram aliquots of total protein from each sample were run on $10 \%$ sodium dodecyl sulfate-polyacrylamide gels to detect iNOS (130 $\mathrm{kDa})$ and actin (43 kDa). Proteins were electrophoretically transferred to polyvinylidene difluoride membranes (Millipore Corp., Bedford, MA), with the membranes blocked with nonfat milk and $0.1 \%$ Tween 20 in Trisbuffered saline for 1 hour at room temperature. The sample was incubated with primary antibodies diluted 1:1000 in skim milk overnight at $4^{\circ} \mathrm{C}$ for specific immunodetection (rabbit polyclonal antibody to iNOS, $\alpha$ Diagnostic Intl Inc., San Antonio, TX; mouse polyclonal antibody to actin, Millipore Corp.). After three washes with PBS, the membranes were incubated for another hour with horseradish peroxidase-conjugated goat anti-rabbit or goat antimouse IgG diluted 1:10,000 in PBS at room temperature. Antigens were revealed by using ECL Plus Western Blot- 
Table 1. Primary Antibodies Employed

\begin{tabular}{|c|c|c|c|c|c|}
\hline Primary antibodies & Source & Identification & Dilution & Type & Specificity \\
\hline NG2 & Chemicon & ab5320 & $\begin{array}{l}1: 200 \text { (dilution with } \\
1 \% \text { BSA-PBS) }\end{array}$ & $\begin{array}{l}\text { Rabbit polyclonal } \\
\text { antibody }\end{array}$ & $\begin{array}{l}\text { Reacts with NG2 of } \\
\text { mouse, rat, and human }\end{array}$ \\
\hline Desmin & Epitomics & $1466-1$ & $\begin{array}{l}\text { 1:400 (dilution with } \\
\text { 1\% BSA-PBS) }\end{array}$ & $\begin{array}{l}\text { Rabbit } \\
\text { monoclonal } \\
\text { antibody }\end{array}$ & $\begin{array}{l}\text { Reacts with desmin of } \\
\text { mouse, rat, and human }\end{array}$ \\
\hline $\mathrm{F} 4 / 80$ & $\begin{array}{l}\text { Santa Cruz } \\
\text { Biotechnology }\end{array}$ & ab6640 & $\begin{array}{l}\text { 1:100 (dilution with } \\
\text { 1\% BSA-PBS) }\end{array}$ & $\begin{array}{l}\text { Rat monoclonal } \\
\text { (Cl:A3-1) to } \\
\text { F4/80 }\end{array}$ & $\begin{array}{l}\text { This antibody recognizes } \\
\text { the mouse F4/80 } \\
\text { antigen, a } 160-k d \\
\text { glycoprotein expressed } \\
\text { by macrophages. }\end{array}$ \\
\hline Collagen type IV & $\begin{array}{l}\text { Research } \\
\text { Diagnostics Inc. }\end{array}$ & 7478 & $\begin{array}{l}1: 50 \text { (dilution with } \\
1 \% \text { BSA-PBS) }\end{array}$ & $\begin{array}{l}\text { Rabbit polyclonal } \\
\text { antibody }\end{array}$ & $\begin{array}{l}\text { Reacts with most } \\
\text { mammalian type IV } \\
\text { collagen (dilution with } \\
1 \% \text { BSA-PBS) }\end{array}$ \\
\hline CD31 & Abcam & $a b 28364$ & $\begin{array}{l}\text { 1:100 (dilution with } \\
1 \% \text { BSA-PBS) }\end{array}$ & $\begin{array}{l}\text { Rabbit polyclonal } \\
\text { antibody }\end{array}$ & Reacts with mouse \\
\hline CXCR4 & Abcam & $a b 2074$ & $\begin{array}{l}\text { 1:100 (dilution with } \\
1 \% \text { BSA-PBS) }\end{array}$ & $\begin{array}{l}\text { Rabbit polyclonal } \\
\text { antibody }\end{array}$ & Reacts with mouse \\
\hline iNOS & $\begin{array}{l}\text { Alpha Diagnostics } \\
\text { Intl. Inc. }\end{array}$ & iNOS-A 0370A2 & $\begin{array}{l}\text { 1:1000 (dilution with } \\
\text { 1\% BSA-PBS) }\end{array}$ & $\begin{array}{l}\text { Rabbit polyclonal } \\
\text { antibody }\end{array}$ & Reacts with mouse \\
\hline
\end{tabular}

BSA, bovine serum albumin.

ting Detection Reagents (GE Healthcare, Pittsburgh, PA). To quantify the changes of iNOS protein level, the band density was analyzed by using Image J software (V1.38X; $\mathrm{NIH}$, West Chester, PA). The density of the bands of actin was used to normalize the iNOS protein level.

\section{Reverse Transcription-Polymerase Chain Reaction}

Total RNA from the cochlear lateral wall was separately extracted for each experimental group with a RNeasy kit (Qiagen, Valencia, CA) according to the manufacturer's suggestions. Each cohort of two mice was analyzed for iNOS mRNA. One microgram of total RNA was reversetranscribed by using a RETROscript kit (Ambion, Austin, TX). Conserved regions spanning introns were selected for the primers of iNOS and glyceraldehyde-3-phosphate dehydrogenase. The primers used were as follows: iNOS (mouse Chr 11 NM_010927), forward, 5' -CTATCAGGAAGAAATGCAGGAGAT-3', reverse, 5'-GAGCACGCTGAGTACCTCATT-3', 145-bp product; SDF-1 $\alpha$ (mouse Chr 6 NM_013655), forward, 5'-CAAGAGGCTCAAGATGTGAGAGGTG-3', reverse, 5'-TGGCCTTGGCCTGTCACCAA-3', 258-bp; and glyceraldehyde-3-phosphate dehydrogenase (mouse Chr 6 NM_008084), forward, 5'-ATGTGTCCGTCGTGGATCTGAC-3', reverse, 5'-AGACAACCTGGTCCTCAGTGTAG-3', 132-bp product. The RT-PCR was cycled at $95^{\circ} \mathrm{C}$ for 2 minutes, up to 40 cycles at $95^{\circ} \mathrm{C}$ for 30 seconds, $60^{\circ} \mathrm{C}$ for 45 seconds, $72^{\circ} \mathrm{C}$ for 30 seconds, and a final 5-minute extension at $72^{\circ} \mathrm{C}$. The products of RT-PCR were visualized by agarose gel electrophoresis.

\section{Quantitative Real-Time Polymerase Chain Reaction}

Total RNA from the cochlear lateral wall of different groups was separately extracted with RNeasy (Qiagen) according to the manufacturer's suggestions. Each cohort of two mice was analyzed for mRNA levels of iNOS and $S D F-1 \alpha$ with quantitative real-time PCR. One microgram of total RNA was reverse-transcribed by using a RETROscript kit (Ambion). The cDNA synthesized from total RNA was diluted 10-fold with DNase-free water, and each cDNA sample was independently tested three times. Transcript quantities were assayed by TaqMan gene expression assay: iNOS (category number Mm01309902_m1; Applied Biosystems, Foster City, $\mathrm{CA}$ ) and SDF-1 $\alpha$ (category number Mm00457276_m1, Applied Biosystems) were assayed in a model 7300 realtime PCR system (Applied Biosystems). Cycling conditions of the real-time PCR were $95^{\circ} \mathrm{C}$ for 20 seconds, 40 cycles of $95^{\circ} \mathrm{C}$ for 1 second, and $60^{\circ} \mathrm{C}$ for 20 seconds. Mouse glyceraldehyde-3-phosphate dehydrogenase (category number 4352339E, Applied Biosystems) expression was used as an endogenous control. Quantitative PCR was performed according to the guidelines provided by Applied Biosystems. The comparative cycle threshold $\left(C_{T}\right)$ method ( $\Delta \Delta C_{T}$ quantitation) was used to assess the difference between samples. Quantitative data analysis followed the suggestions of the manufacturer.

\section{Enzyme-Linked Immunosorbent Assay}

To compare the protein level of SDF-1 between different groups, whole cochlea was isolated from the animals (cohorts of three animals) and the lateral wall tissue carefully dissected. All tissue samples were homogenized in lysis buffer (RIPA Lysis buffer, Upstate, a Serologicals Company) with a protease inhibitor cocktail (Protease Inhibitor cocktails Set III, Calbiochem) for 30 seconds. After centrifuging $\left(4^{\circ} \mathrm{C}, 30\right.$ minutes, at $\left.14,000 \mathrm{rpm}\right)$, the supernatant was collected, and the protein assay was performed by using a DC protein Assay kit (Bio-Rad). Ten 
micrograms of protein per sample was used for enzymelinked immunosorbent assay (ELISA) analysis. SDF-1 protein concentration of different groups was assessed by using a Quantikine Mouse CXCL12/SDF-1 ELISA kit (R\&D Systems, Burlington, ON) according to the manufacturer's recommendations.

\section{$\mathrm{GFP}^{+}-\mathrm{BMDC}$ Count}

$\mathrm{GFP}^{+}$-BMDCs in the stria vascularis of mouse cochlea were counted on a standard epifluorescence microscope with $\mathrm{a} \times 40$ objective lens (cohorts of four mice). The $\mathrm{GFP}^{+}$-BMDCs were counted in a region corresponding to an initial frequency response of $8-32 \mathrm{kHz}$, determined by the frequency-map described by Wang et al. ${ }^{22}$ Noisecaused hearing loss occurs predominately between 8 and $32 \mathrm{kHz}$ with this sound protocol. ${ }^{6}$ The area studied in this investigation (a length approximately $2 \mathrm{~mm}$ starting $1.5 \mathrm{~mm}$ from the base) lies within this region. For plotting purposes, the data were grouped.

\section{Drug Treatment}

The mice were pretreated with $1400 \mathrm{~W}$ (10 mg/kg, i.p.; Enzo Life Sciences, Farmingdale, NY) ${ }^{23}$ to inhibit iNOS and with an antagonist of the SDF- $1 \alpha$ receptor CXCR4, AMD3100 (7.5 mg/kg, i.p.; Sigma-Aldrich), ${ }^{24}$ to inhibit SDF- $1 \alpha$ activity. Treatments were administered as singledose injections 30 minutes before the animal received noise and were continued at one dose per day for the first week and one dose per week up to 4 weeks after noise exposure. The side-effects of 1400W and AMD3100 on auditory function were evaluated. Auditory brain-stem response was used to measure hearing threshold. Neither 1400W nor AMD3100 showed ototoxicity in the six mice of the two treated groups.

\section{NO Measurement}

The auditory bulla was dissected and rapidly opened in a petri dish filled with a physiological solution containing
$125 \mathrm{mmol} / \mathrm{L} \mathrm{NaCl}, 5.0 \mathrm{mmol} / \mathrm{L} \mathrm{KCl}, 1.6 \mathrm{mmol} / \mathrm{L} \mathrm{CaCl}_{2}, 18$ $\mathrm{mmol} / \mathrm{L} \mathrm{NaHCO}_{3}, 10 \mathrm{mmol} / \mathrm{L}$ glucose, and $10 \mathrm{mmol} / \mathrm{L}$ HEPES, pH 7.4. Small pieces of tissue from the basal middle turn of the cochlear lateral wall in noise exposed animals, both with and without 1400W treatment, were removed and incubated in a physiological solution at $37^{\circ} \mathrm{C}, \mathrm{pH} 7.4$, containing $10 \mu \mathrm{mol} / \mathrm{L}$ diaminofluorescein-2 diacetate (category number 251505, Calbiochem) for detecting NO. The tissue was incubated with dye for 30 minutes, subsequently washed in fresh physiological solution for 10 minutes, and assessed by confocal microscopy. Quantitation of the NO indicator was performed on images taken at the same gain and illumination power setting (488 excitation, $520 \mathrm{~nm}$ emission filter for the diaminofluorescein diacetate). Fluorescence intensity was analyzed by using Image J software (V1.38X; NIH) as described previously. ${ }^{4}$ In brief, images were acquired with a $\times 40$ objective lens. A total of 12 to 16 images were recorded from four normal mice. Twelve to 14 images from four noise-exposed mice were recorded. A total of 13 to 17 images were recorded from four $1400 \mathrm{~W}$-treated noise-exposed mice. The area of the stria vascularis was analyzed for mean fluorescence intensity. Mean background fluorescence, obtained for a small area located away from the fluorescent tissue, was subtracted from the fluorescence intensity. Presented data are an average of four experimental and control animals.

\section{Vascular Density Measurement}

The entire length of the mouse stria vascularis (from apex to base) is about $6.25 \mathrm{~mm}$ (Figure 1A). For each cochlea, the capillary density was measured within a $1.25-\mathrm{mm}$ region beginning at $1.5 \mathrm{~mm}$ from the base. Capillaries in the stria vascularis were visualized by collagen IV labeling (Figure 1B). The vessels were traced manually (Figure $1 \mathrm{C})$. The area of the stria vascularis was determined from a differential interference contrast image (Figure 1D). The pixel area of the capillary and the pixel area of the stria vascularis were determined by using the ImagePro Plus program (Media Cybernetics, Inc., Bethesda,

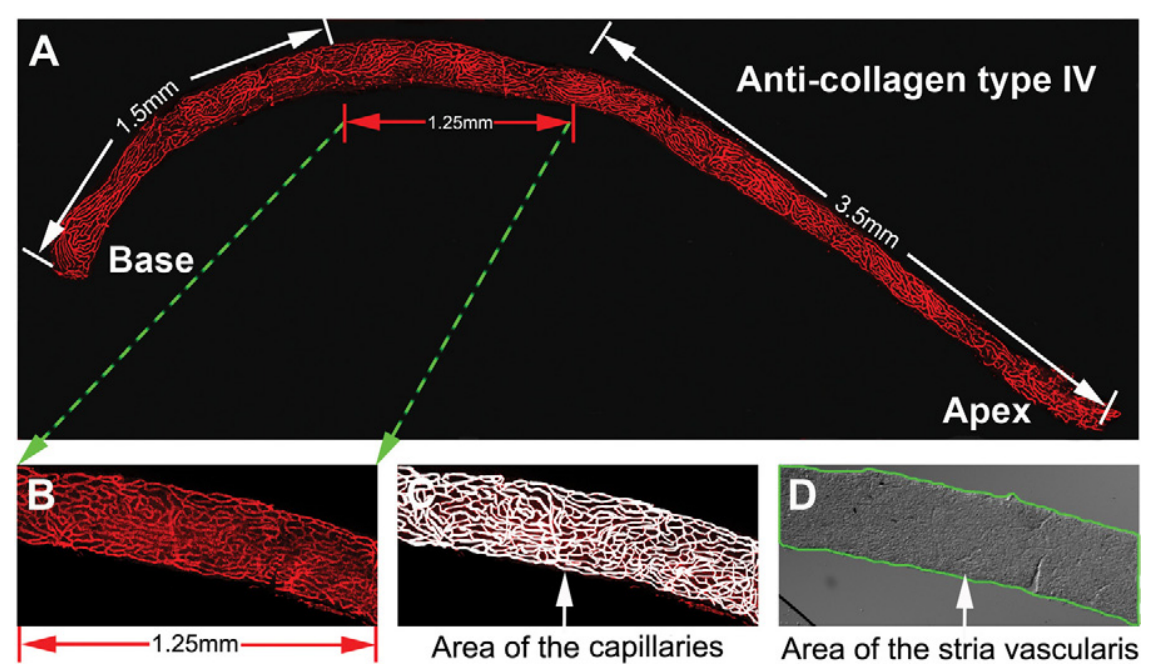

Figure 1. Measurement of capillary density in the stria vascularis. A: A montage of the stria vascularis pieces, showing the entire length of the mouse stria vascularis. B: Delineation of the portion of the stria vascularis examined. C: The capillary network manually traced out in the measured region. D: Outer boundaries define the area of the stria vascularis; corresponding to the location of the capillary area was determined from a differential interference contrast image. 
MD). Capillary density as a percentage of the strial tissue was calculated as $\frac{\text { Pixel area of capillaries }}{\text { Pixel area of the stria vascularis }} \times 100 \%$.

\section{Statistics and Analysis}

Data are presented as means \pm SD and were evaluated by using the Student's t-test for two groups or by analysis of variance for comparisons of three or more groups. A 95\% confidence level was considered statistically significant.

\section{Results}

\section{Bone Marrow Cells Recruited to Noise-Damaged Blood-Labyrinth-Barrier}

The cochlea of the mouse has 2.5 turns of lateral wall (Figure 2A). The normal mouse cochlear lateral wall contains two dense networks of capillaries: the capillaries of the stria vascularis (V/SV) and the capillaries of the spiral ligament (V/SL; Figure 2B, modified from Mudry and
A

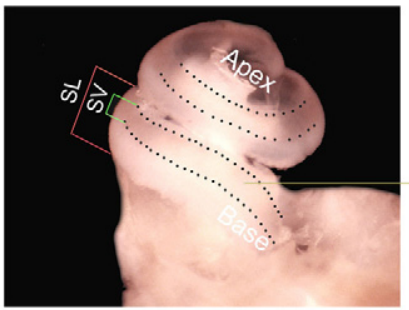

C GFP $^{+}$-bone marrow cells into wild type bone marrow depleted mouse

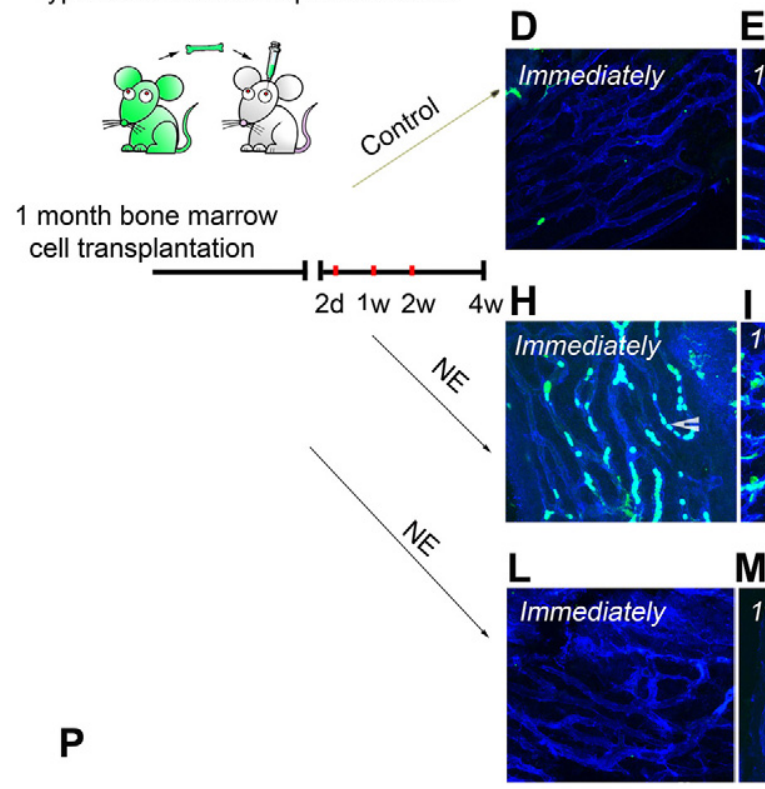

B

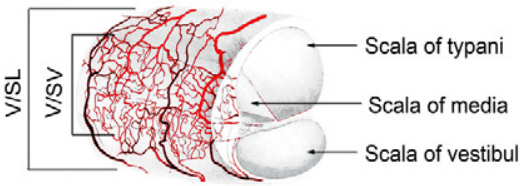

GFP $^{+}$-BMDCs+Collagen type IV

E

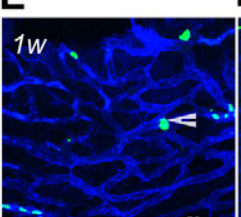

$\mathbf{F}$

$2 w$

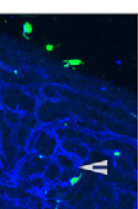

G
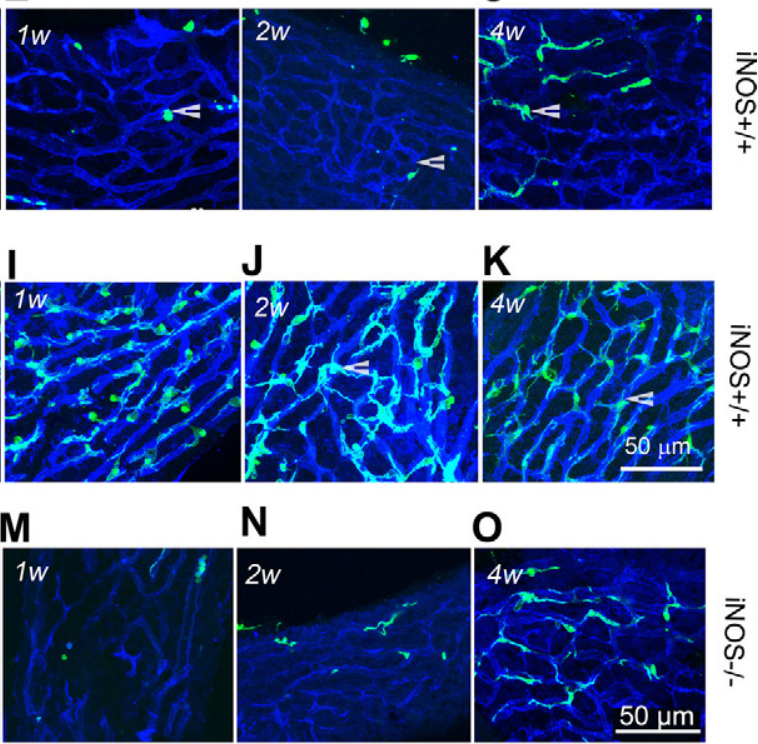

N

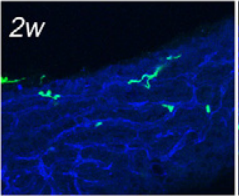

0

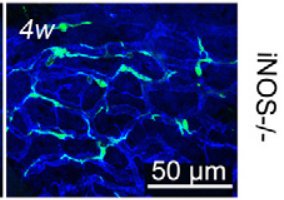

$\mathrm{GFP}^{+}$-BMDCs+Collagen type IV

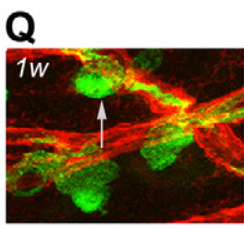

$\mathbf{R}$

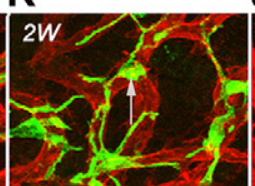

\section{$\sum_{0}$
O
+}

\section{$\sum_{0}$
D
\pm}

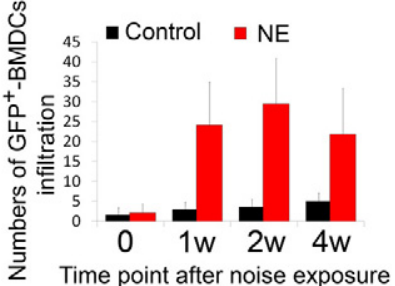

$(120 \mathrm{~dB} / 3 \mathrm{~h} / 2 \mathrm{~d})$

Figure 2. Noise initiates robust $\mathrm{GFP}^{+}$-BMDC infiltration into the damaged CBLB. A: A dissecting scope image of the cochlea. A drawn dotted line indicates the location of the stria vascularis (SV) where the CBLB is located. The wide bracket demarks the width of the spiral ligament (SL), whereas the narrow bracket demarks the stria vascularis (SV). B: A drawing illustrates the two capillary networks, the vessels of the spiral ligament (V/SL), and the vessels of the stria vascularis (V/SV) in the cochlear lateral wall (modified from Mudry and Tange ${ }^{25}$ ). C: A cartoon depicts the transfer of green fluorescent bone marrow cells from GFP mice to irradiated non-GFP mice by periorbital sinus injection. Transplanted animals were allowed to recover 1 month before testing. The diagram sets out the time line for animal transplantation and sacrifice. D-G: show $\mathrm{GFP}^{+}-\mathrm{BMDC}$ infiltration (green and white arrowheads) from capillaries of the stria vascularis (blue, labeled with antibody for collagen type IV) in a control iNOS WT mouse. H-K and $\mathbf{L}-\mathbf{O}$, respectively, show GFP ${ }^{+}$-BMDC infiltration (white arrowheads) from capillaries of the stria vascularis in a noise-exposed iNOS WT mouse and a noise-exposed Inos $^{-1-}$ mouse. P: The difference in infiltration of GFP ${ }^{+}$-BMDCs in control and noise-exposed groups is statistically significant $\left(n=4 ; P_{0}=0.48 ; P_{1 \mathrm{w}}<0.001 ; P_{2 \mathrm{w}}<0.001 ; P_{4 \mathrm{w}}=0.001\right)$. Q-S: Morphological features of $\mathrm{GFP}^{+}$-BMDCs (green and white arrows) at week 1, week 2, and week 4 are displayed (see Results). Images shown are projections of confocal z-stacks taken at tested time points. 
Tange). ${ }^{25}$ The strial capillaries, shaped as polygonal loops, are highly specialized vascular epithelia that form the CBLB in the stria vascularis. Sound trauma causes a significant breech of the CBLB. ${ }^{6}$

In this study, we investigated whether BMDCs have an essential role in repair of damaged cochlear microvessels in the stria vascularis. Lethally irradiated mice were transplanted with GFP ${ }^{+}$-BMDCs from C57BI/6-Tg (UBCGFP) mice (Figure 2C). One month after transplantation, we assessed the population of $\mathrm{GFP}^{+}$-BMDCs in the region of the stria vascularis in the reconstituted INOS WT and Inos $^{-1-}$ mice under control (not exposed to loud sound) and acoustic trauma conditions. Irradiated and BMDC transplanted control mice showed normal hearing thresholds immediately after irradiation and 2 months after irradiation (data not shown). No GFP ${ }^{+}$-BMDCs were observed to have migrated into the area of the stria vascularis in the control mice at 1 month post transplantation. Only small numbers of $\mathrm{GFP}^{+}$-BMDCs had infiltrated into the area of CBLB 2 months after transplantation in the reconstituted iNOS WT mice (Figure 2, D-G). Then, when animals were exposed to wide-band noise at $120 \mathrm{~dB}$ for 3 hours per day for 2 consecutive days, robust BMDC migration was observed in the acoustically traumatized iNOS WT animal cochlea (Figure 2, H-K). Immediately after noise exposure and flushing by cardiac perfusion, large numbers of $\mathrm{GFP}^{+}$-BMDCs were observed adhered to vessel walls in the capillary network. These labeled cells had not yet transmigrated across the vessel wall at this time point. Remarkably, GFP ${ }^{+}$-BMDC infiltration occurred in the first week post acoustic trauma. GFP $^{+}$-BMDCs further accumulated at the second week (Figure 2, H-K). However, much less GFP $^{+}$-BMDCs infiltration was observed in the Inos $^{-/-}$mice (Figure 2, L-O). The number of the infiltrated $\mathrm{GFP}^{+}$-BMDCs is shown in Figure 2P. There was a significant difference in $\mathrm{GFP}^{+}$. BMDC infiltration between the control and noise-exposed iNOS WT mice.

Infiltrated BMDCs were previously identified as macrophages. ${ }^{26}$ After taking residence in the stria vascularis, they underwent morphological changes (Figure 2, Q-S). At an early stage (approximately 1 week post noise exposure), infiltrated $\mathrm{GFP}^{+}$-BMDCs were frequently found to be spherical or nodular shaped (possibly caught in the act of transmigration, Figure $2 \mathrm{Q}$ ). Approximately 2 weeks post noise exposure, most of infiltrated $\mathrm{GFP}^{+}$-BMDCs developed ramified processes, appeared dendriform in shape, and were irregularly distributed on the capillaries of the stria vascularis (Figure 2R). Approximately 4 weeks post noise exposure, the majority of infiltrated BMDCs were elongated and displayed a particular orientationthat is, their long processes were parallel to the vessels of the stria vascularis (Figure 2S).

\section{BMDC Infiltration Mediated by NO from iNOS}

eNOS was previously reported to be essential in the recruitment of peripheral circulating bone marrow cells to the sites of ischemia. ${ }^{21}$ Our finding of noise-induced iNOS expression in the cochlear lateral wall, ${ }^{27}$ however,
A
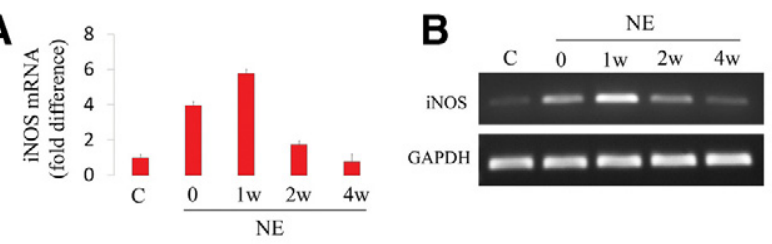

C

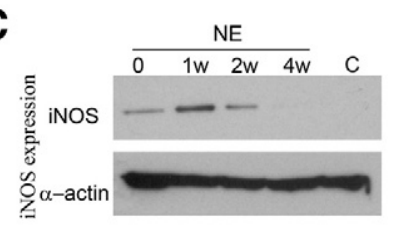

D

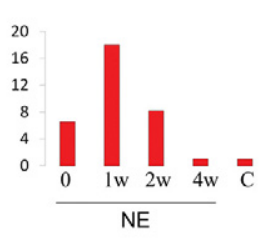

E

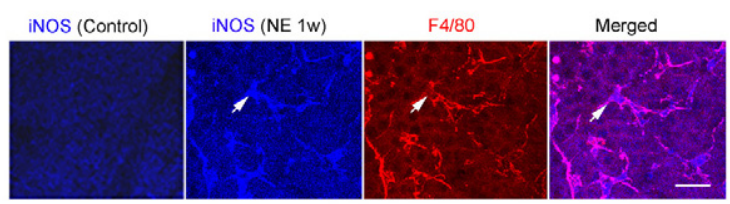

$\mathbf{F}$

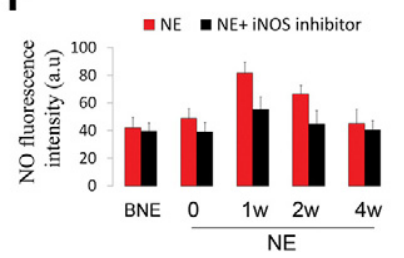

G

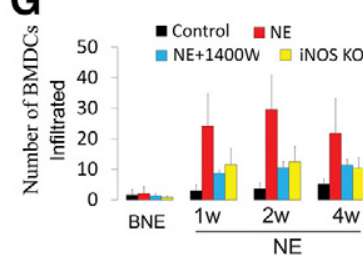

Figure 3. Noise induced iNOS expression promotes BMDC infiltration. A and B: Results from quantitative real-time PCR (A) show that mRNA for Inos significantly increased after noise exposure $\left(n=5 ;{ }^{* *} P_{0}<0.01 ;{ }^{* *} P_{1 \mathrm{w}}<\right.$ $\left.0.001 ;{ }^{*} P_{2 \mathrm{w}}<0.05\right)$. An agarose gel analysis of RT-PCR products $(\mathbf{B})$ corroborates the results. C and D: A Western blot analysis also shows increased expression of iNOS in the noise-exposed mice. E: iNOS immunoreactivity (blue) was found in resident macrophages (white arrows, labeled for F4/80, red). F: NO production increased after noise exposure $\left(n=4 ; P_{\mathrm{ONE}}<0.05\right.$ $\left.P_{1 \mathrm{wNE}}<0.001 ; P_{2 \mathrm{wNE}}<0.001 ; P_{4 \mathrm{wNE}}=0.10\right)$. G: BMDC infiltration was significantly lower in noise-exposed Inos $^{-/-}$mice and $1400 \mathrm{~W}$ treated noiseexposed WT mice than in noise-exposed controls measured at the same time points $\left(n=4, \mathrm{WT}_{\mathrm{NE}} / \operatorname{Inos}_{\mathrm{NE}}^{-/-}: P_{0}=0.487, P_{1 \mathrm{w}}<0.01, P_{2 \mathrm{w}}<0.05, P_{4 \mathrm{w}}<0.05\right.$; $\mathrm{WT}_{\mathrm{NE}} / \mathrm{WT}_{\mathrm{NE}+1400 \mathrm{w}}: P_{0}=0.088, P_{1 \mathrm{w}}<0.01, P_{2 \mathrm{w}}<0.05, P_{4 \mathrm{w}}<0.05 ; \mathrm{C}$, control; NE, noise exposure; BNE, before noise exposure)

has opened the question of whether iNOS, another isoform of the synthase, is mediating BMDC infiltration. Quantitative real-time PCR demonstrated the mRNA level for Inos increased immediately after noise exposure and remained at an elevated level for at least 1 week (Figure $3 A)$. Analysis of the products of reverse transcriptasePCR by agarose gel (Figure 3B) also showed increased mRNA level for Inos increased after noise exposure. In agreement with the induction of mRNA for Inos, increased expression of iNOS protein measured by Western blot analysis was also detected immediately after noise exposure (Figure 3, C and D). iNOS expression peaked at 1 week post noise exposure, but was undetectable at 4 weeks. Immunohistochemistry combined with confocal microscopy showed no iNOS immunoreactivity in the control stria vascularis. In contrast, the expression of iNOS was found in the stria vascularis, particularly in perivascular resident macrophages (PVMs) double labeled with antibodies for macrophage marker protein F4/80 and iNOS in the noise-exposed mice (Figure 3E). To further analyze the iNOS activity, tissues were incubated with diaminofluorescein-2 diacetate, a fluorescent 


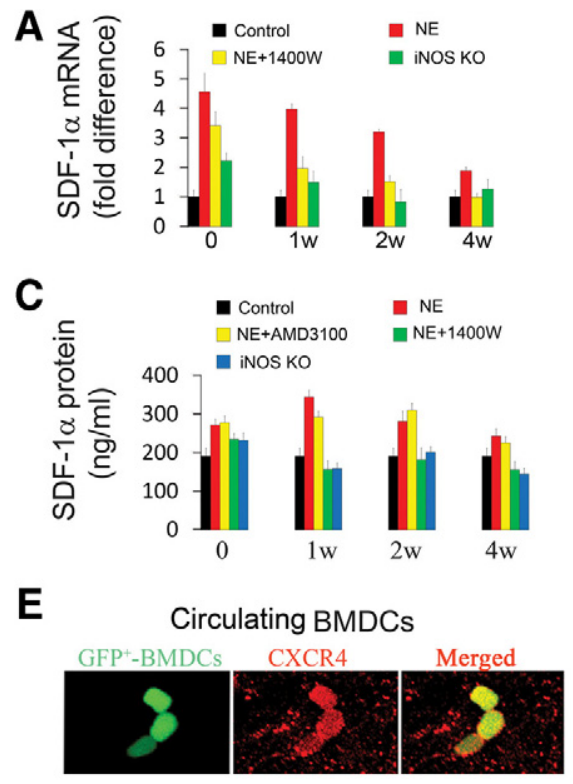

B

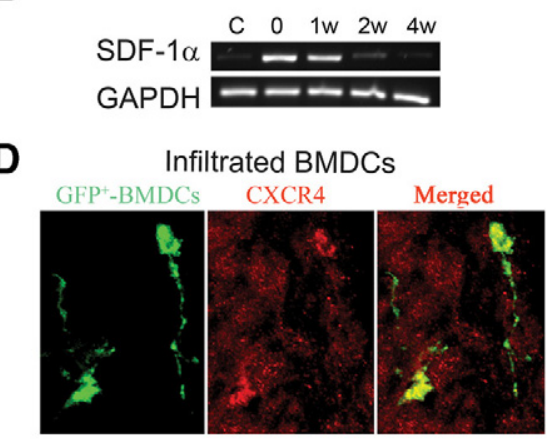

Figure 4. iNOS up-regulates SDF- $1 \alpha$ expression, which, in turn, promotes BMDC infiltration. $\mathbf{A}$ and $\mathbf{B}$ show increased mRNA expression for $S d f-1 \alpha$ in noise-exposed mice relative to controls $\left(n=3 ; P_{\mathrm{ONE}}<0.001 ; P_{1 \mathrm{wNE}}<0.001 ; P_{2 \mathrm{wNE}}<\right.$ $\left.0.01 ; P_{4 \mathrm{wNE}}=0.054\right)$. C: Noise-exposed mice expressed more SDF- $1 \alpha$ protein than unexposed controls $\left(n=3 ; P_{\mathrm{ONE}}<0.01 ; P_{1 \mathrm{wNE}}<0.01\right.$; $\left.P_{2 \mathrm{wNE}}<0.05 ; P_{4 \mathrm{wNE}}=0.09\right)$. CXCR4 immunoreactivity was detected in migrated $(\mathbf{D})$ and circulating $\mathrm{GFP}^{+}$-BMDCs $(\mathbf{E})$. The merged panels in $\mathbf{D}$ and $\mathbf{E}$ show co-location of the GFP and CXCR4 labels in the $\mathrm{GFP}^{+}-$BMDCs. F: Infiltration of $\mathrm{GFP}^{+}$-BMDCs in noise-exposed and $\mathbf{F}$

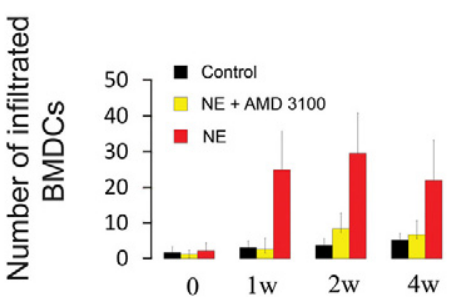
AMD3100 treated noise-exposed mice compared with controls $\left(n=4 ; P_{\mathrm{ONE}}=0.46 ; P_{1 \mathrm{wNE}}<0.001\right.$; $P_{2 \mathrm{wNE}}<0.001 ; P_{4 \mathrm{wNE}}=0.001 ; n=4$ $P_{\text {ONE }+ \text { AMD } 3100}=0.288, P_{1 \mathrm{wNE}+\mathrm{AMD} 3100}<0.01$ $P_{2 \mathrm{wNE}+\mathrm{AMD} 3100}<0.001, P_{4 \mathrm{wNE}}<0.01 ; \mathrm{C}$, control $\mathrm{NE}$, noise exposure).

indicator for NO. Consistent with the results of increased immunoreactivity for iNOS, a significantly increased level of NO production was found in the stria vascularis of the noise-exposed mice (Figure 3F). Inhibition of iNOS activity with the iNOS inhibitor $1400 \mathrm{~W}$ markedly reduced NO production (Figure 3F). The number of infiltrated BMDCs in noise-exposed Inos $^{-1-}$ mice and in iNOS inhibitor 1400W treated noise-exposed WT mice was significantly less than in noise-exposed WT mice (Figure 3G). The data indicates that NO produced by iNOS is an important driving signal for the recruitment of bone marrow derived cells.

\section{$B M D C$ Infiltration Linked to iNOS Up-Regulation of $S D F-1 \alpha$}

SDF- $1 \alpha$ and its receptor CXCR4 are known to regulate homing and engraftment of BMDCs. ${ }^{28}$ To determine whether iNOS/NO regulated BMDC recruitment involves SDF- $1 \alpha /$ CXCR 4 signaling in the cochlea, SDF- $1 \alpha$ expression in control and noise-exposed WT mice, as well as in Inos $^{-1-}$ mice and WT mice with iNOS inhibition, were compared.

The mRNA level for Sdf- $1 \alpha$ increased immediately after noise exposure and peaked at 1 week post noise exposure (Figure 4, A and B). The noise induced increase of mRNA for $S d f-1 \alpha$ was significantly suppressed when the noise-exposed mice were treated with the iNOS inhibitor, $1400 \mathrm{~W}$. This suppression was also observed in Inos $^{-1-}$ mice. Consistent with noise-induced mRNA up-regulation, the amount of SDF- $1 \alpha$ protein in the stria vascularis, as determined by ELISA, was significantly higher after noise exposure and declined over the following 4 weeks (Figure 4C), reflecting the changes in mRNA (Figure 4, A and $\mathrm{B})$. Reduced SDF- $1 \alpha$ protein expression in the stria vascularis was found in Inos $^{-1-}$ mice and in WT mice treated with an iNOS inhibitor (Figure 4C). Immunohistochemical labeling showed that the CXCR4 receptor con- stitutively expressed in infiltrated and noninfiltrated (circulating) $\mathrm{GFP}^{+}$-BMDCs (Figure 4, D and E). Blocking SDF- $1 \alpha$ activity with the specific blocker, AMD3100, for CXCR4, greatly attenuated BMDC infiltration (Figure 4F). The results support iNOS up-regulation of SDF- $1 \alpha$ for signaling and recruitment of bone marrow cells.

\section{Vascular Repair from Infiltrated BMDCs}

The cochlear microvasculature in the stria vascularis is composed of endothelial cells and accompanied in close approximation by pericytes and the PVMs (Figure 5A). ${ }^{26}$ Endothelial cells were easily visualized with a fluorescent conjugated antibody for mouse IgG (Figure 5A, blue). Pericytes, in close contact with the capillaries, were identified with antibody for desmin (Figure 5A, green). PVMs, enveloping the capillary networks, were identified with an antibody for F4/80 (Figure 5A, red). The three cell types structurally linked (Figure 5A, right).

By 4 weeks post noise exposure, we found that GFP ${ }^{+}$. BMDCs were differentiated into the vascular cells in WT mice (Figure 5, B-F). The majority of infiltrated $\mathrm{GFP}^{+}$. BMDCs differentiated into macrophages as identified by macrophage marker protein F4/80 (Figure 5B). A minority differentiated into pericytes, indentified by pericyte marker protein NG2 (Figure 5C), and endothelial cells, identified by anti-endothelial CD31 (Figure 5D) and antiendothelial IgG (Figure 5E). A low-magnification confocal microscopy image shows the entire GFP-positive vessel structure with incorporated pericytes, endothelial cells, and resident macrophages (Figure 5F).

\section{Inhibition of iNOS/SDF- $1 \alpha$ Reduces Vascular Density in the Stria Vascularis}

Capillary density was evaluated at 4 weeks post noise exposure. The capillaries, labeled with antibody for col- 
A
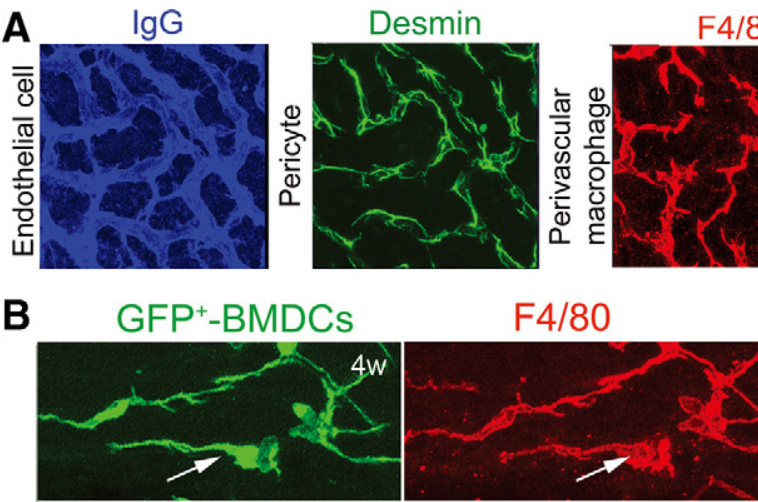

$\mathrm{F} 4 / 80$

B

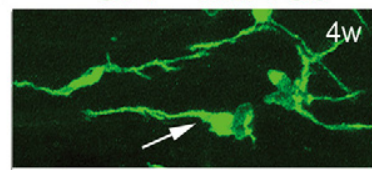

C
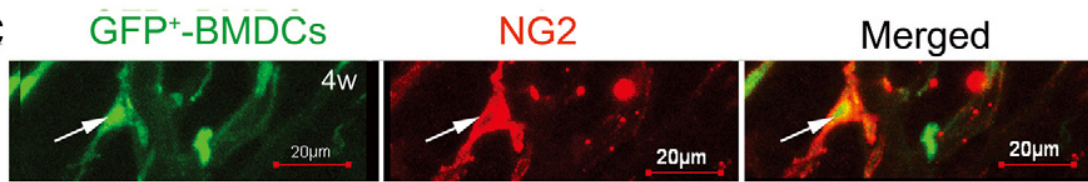

D

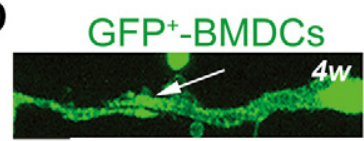

E

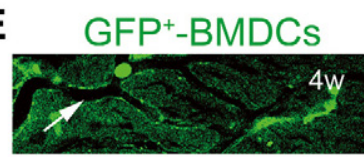

F GFP+-BMDCs
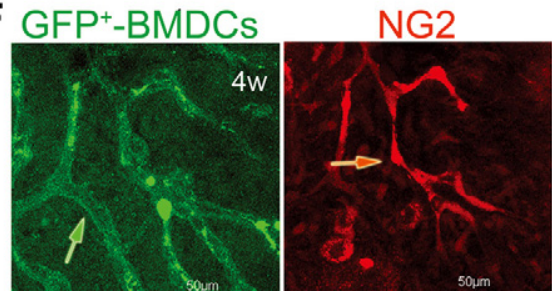

Merged

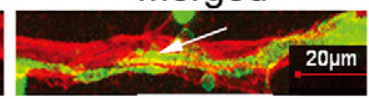

Merged
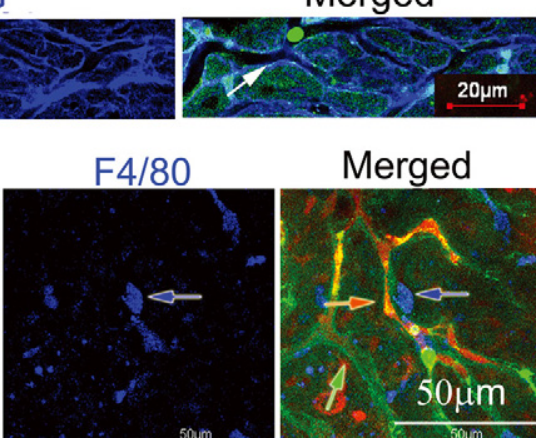

Merged

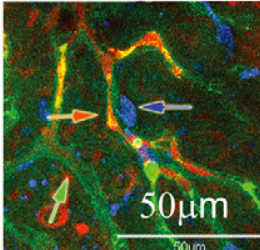

lagen IV, were imaged on a confocal fluorescence microscope, and capillary density calculated as a ratio of pixel area of capillaries to the pixel area of capillaries in the stria vascularis. Capillary density was significantly higher in high BMDC infiltrated noise-exposed WT mice than in BMDC infiltrated noise-exposed Inos $^{-1-}$ mice, $1400 \mathrm{~W}$ treated WT mice, or AMD3100 treated mice. The latter three groups showed statistically significant decrease in capillary density as compared with noise-exposed WT mice (Figure 6A). Typical examples of the defects in vascular density in Inos $^{-1-}$ mice and drug treated noiseexposed WT mice are presented in Figure 6B. The data indicate that inhibition of iNOS/SDF- $1 \alpha$ inhibits damaged capillary repair in the stria vascularis.

\section{Discussion}

Repair of ischemic noise-damaged CBLB involves recruitment of bone marrow cells through an intrinsic iNOSdependent SDF-1 $\alpha$ signaling pathway. Peripheral bone marrow cell mobilization and vascularization in the traumatized CBLB contribute to repair of the damaged CBLB and improvement of microvessel density.
In this study, we found robust $\mathrm{GFP}^{+}$-BMDC recruitment in the injured cochlea after noise exposure. The results are consistent with earlier reports of BMDC migration in noise-exposed cochlea. ${ }^{29,30}$ Local iNOS is required for the recruitment, as evidenced by the suppression of BMDC infiltration in iNOS knockout mice and in mice treated with $1400 \mathrm{~W}$, a specific iNOS inhibitor. The peak of BMDC recruitment, occurring at 7 to 14 days, corresponds with the peak in NO production (Figure 3).

$\mathrm{NO}$ is synthesized by a class of NADPH-dependent NOSs, which catalyze the conversion of L-Arginine to L-Citrulline and NO. ${ }^{31}$ There are three known NOS isoforms: neuronal NOS, eNOS, and iNOS. Neuronal NOS and eNOS are constitutive, calcium-dependent synthases, which produce a low level of NO. In contrast, iNOS, induced by inflammatory cytokines ${ }^{32}$ is calciumindependent and produces large amounts of NO.

$\mathrm{NO} / \mathrm{N} N \mathrm{~S}$ initiated angiogenesis has recently been reported in mouse hind limbs. ${ }^{33}$ Inhibition of eNOS activity blocks angiogenesis and wound healing. ${ }^{34,35}$ However, involvement of iNOS in the homing of BMDCs to injured tissue has not been previously reported. In this study, we provided the first evidence that NO produced by iNOS is 
A

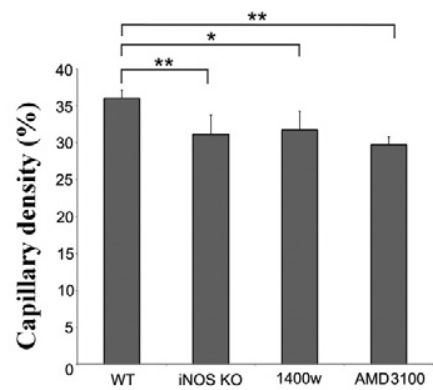

B

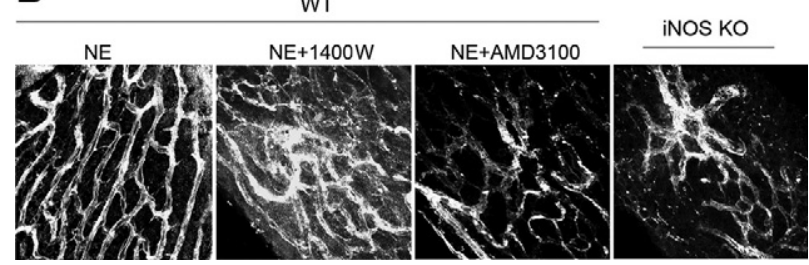

Figure 6. Inhibition of iNOS and block of CXCR4 receptor result in a reduction of strial capillary density. A: Capillary density in the stria vascularis with respect to WT controls was significantly decreased in the experimental groups $\left(n=3 ;{ }^{*} P_{\mathrm{WTNE} / \mathrm{WTNE}+1400 \mathrm{~W}}<0.05 ;{ }^{* * *} P_{\mathrm{wtNE} / \text { Inos }-/-\mathrm{NE}}<0.01\right)$. B Confocal projection images from different groups at 4 weeks post noise exposure showed the decreased densities of the capillary networks of the stria vascularis in the Inos $^{-1-}$ mice and 1400W and AMD3100 treated noiseexposed mice.

important for BMDC infiltration in the stria vascularis. Infiltration of BMDCs is significantly reduced in 1 nos $^{-1-}$ mice, wild-type mice treated with an iNOS inhibitor, or with blockage of the CXCR4 receptor. Note that BMDC homing is inhibited in Inos $^{-1-}$ mice lacking iNOS in resident macrophages. Although normal gene expression would occur in the transplanted BMDCs, only very few of these normally iNOS expressing cells integrate into the stria vascularis at the time of sound exposure.

Acoustic trauma causes inflammation of the cochlear lateral wall, ${ }^{30,36}$ induces NO, and releases cytokines. $6,37,38$ The change in NO production with noise exposure is dramatic. ${ }^{2,27}$ In this study, we found iNOS expressed primarily in PVMs, although the possibility other cell types such as vascular cells and nonvascular cells also express iNOS was not excluded. iNOS in resident macrophages is one source of NO production. PVMs are known to have a role in immunological defense and repair. ${ }^{39}$ They also act as immune or immuno-effector cells by producing superoxide anions, NO, and inflammatory cytokines in inflammation. ${ }^{40}$ Recent evidence has shown that the microglia produce neurotrophic and neuroprotective molecules important for neuron survi$\mathrm{val}^{41}$ in brain and for vascular repair in the retina. ${ }^{42}$ The current work demonstrates that production of $\mathrm{NO}$ by PVMs also has a role in BMDC recruitment.

eNOS enzymatic activity may also contribute to increased NO production after noise exposure. NO production under conditions of low iNOS activity can be attributed to eNOS, an enzyme constitutely expressed in endothelial cells under normal conditions ${ }^{43}$ and unregulated after noise exposure. ${ }^{44}$ As evidence of the eNOS contribution, inhibition of iNOS expression does not abolish BMDC infiltration, nor does inhibition of iNOS elimi- nate NO production in the cochlear lateral wall. $\mathrm{NO}$ is detected in the lateral wall with low iNOS expression.

Bone marrow cell recruitment is signaled by a rich milieu of chemokines in the local microenvironment. ${ }^{45}$ BMDCs are able to sense sites of chemokine release from injured or inflamed tissue. SDF- $1 \alpha$ and its receptor CXCR4 play major roles in this signaling, particularly for recruitment of progenitor cells to ischemic tissues. ${ }^{18,19,46}$ Blockage of the CXCR4 site on circulating cells prevents recruitment to sites of injury. ${ }^{47}$ Up-regulation of SDF- $1 \alpha$, on the other hand, promotes angiogenesis and enhances inflammatory cell infiltration, facilitating collagen synthesis in the wound bed. ${ }^{48,49}$

We hypothesize that iNOS induced BMDC infiltration occurs through SDF- $1 \alpha$ signaling. Expression of SDF- $1 \alpha$ in the noise-exposed cochlea is significantly up-regulated at both the mRNA and protein levels (results consistent with Tan et al). ${ }^{29}$ While inhibition of iNOS activity decreases the level of SDF- $1 \alpha$ in the stria vascularis, how the two proteins interact is not clear. The peak in iNOS mRNA expression occurs approximately 1 week after noise exposure, whereas peak in SDF- $1 \alpha$ expression occurs immediately. We presume regulation of genes of iNOS and SDF- $1 \alpha$ through different signaling pathways. Studies have shown SDF- $1 \alpha$ gene expression regulated by induction of hypoxia-inducible factor- 1 in ischemic endothelial cells ${ }^{50}$ and by up-regulation of vascular endothelial growth factor. ${ }^{51}$ Given that both hypoxia-inducible factor-1 and vascular endothelial growth factor are up-regulated immediately by noise exposure, ${ }^{6}$ these, or other candidates, may be responsible for the high expression of SDF- $1 \alpha$. iNOS, on another hand, is regulated by proinflammatory cytokines such as nuclear factor kappa-light-chain-enhancer of activated B cells, tumor necrosis factor $\beta$, and interleukin. ${ }^{52,53}$

Blockage of the SDF- $1 \alpha$ receptor CXCR4, expressed on BMDCs, eliminates BMDC migration to the cochlea. The results are consistent with iNOS promotion of BMDC infiltration in the cochlea through NO induced up-regulation of SDF- $1 \alpha$ expression. eNOS-dependent SDF- $1 \alpha /$ CXCR4-mediated peripheral bone marrow stem cell infiltration to the ischemic heart has been reported through a cGMP signaling pathway. ${ }^{21}$ Analogous pathways for iNOS induced BMDC recruitment may be activated in the acoustically-damaged ear.

The recruited BMDCs show morphological changes with time. The earliest infiltrated $\mathrm{GFP}^{+}-\mathrm{BMDCs}$ are approximately spherical in shape. By 2 weeks, the BMDCs have ramified processes, and are distributed along the capillary network. At 4 weeks post noise exposure, the majority of the infiltrated BMDCs are situated on the vessels of the stria vascularis as pericytes, endothelial cells, and PVMs (Figure 5). The recruited macrophages act in a manner consistent with their recruitment in other tissues, where they promote angiogenesis and neovascularization. ${ }^{10}$

Noise exposure reduces capillary density and cochlear blood flow perfusion. ${ }^{54}$ The present study revealed a significant reduction of capillary density in Inos deficient mice and in mice treated with an iNOS inhibitor or SDF-1 $\alpha$ receptor blocker (blocking BMDC recruitment). Vascular repair was seen in wild type mice after 
noise exposure, but little vascularization presented in Inos $^{-1-}$ mice, wild type mice treated with an iNOS inhibitor, or in mice in which the CXCR4 receptor was blocked. The results are consistent with angiogenesis from bone marrow derived cells.

Tissue re-oxygenation and re-establishment of normal energy supply are essential for functional recovery after noise injury. Cochlear cells, especially sensory hair cells, are quite vulnerable to hypoxia. Metabolites that accumulate during increased sound activity must be quickly removed, and for this, the integrity of the capillary network is required. Repair and restoration of the cochlear capillary network via bone marrow cell recruitment is essential for facilitating hearing recovery from noise damage.

\section{Conclusion}

Postnoise injury repair in microvessels of the cochlea involves NO, which is partly produced by the iNOS pathway. Up-regulation of iNOS expression in acousticallytraumatized cochlea promotes migration of BMDCs to damaged CBLB in the stria vascularis. iNOS associated up-regulation of SDF- $1 \alpha$ leads to BMDC migration and repair of damaged vessels. Conversely, inhibition of iNOS decreases resilience to noise insults. Given the role of iNOS in vessel repair, modulation of NO production may provide a therapeutic target for treating acoustic stroke.

\section{Acknowledgment}

We thank Dr. Teresa Wilson for her critical reading and editing of the article.

\section{References}

1. Angoulvant D, Fazel S, Li RK: Neovascularization derived from cell transplantation in ischemic myocardium. Mol Cell Biochem 2004, 264:133-142

2. Shi $X$, Dai C, Nuttall AL: Altered expression of inducible nitric oxide synthase (iNOS) in the cochlea. Hear Res 2003, 177:43-52

3. Nuttall AL: Sound-induced cochlear ischemia/hypoxia as a mechanism of hearing loss. Noise Health 1999, 2:17-32

4. Miller JM, Brown JN, Schacht J: 8-iso-prostaglandin F(2alpha), a product of noise exposure, reduces inner ear blood flow. Audiol Neurootol 2003, 8:207-221

5. Gratton MA, Schmiedt RA, Schulte BA: Age-related decreases in endocochlear potential are associated with vascular abnormalities in the stria vascularis. Hear Res 1996, 102:181-190

6. Shi X: Cochlear pericyte responses to acoustic trauma and the involvement of hypoxia-inducible factor-1alpha and vascular endothelial growth factor. Am J Pathol 2009, 174:1692-1704

7. Lamm K, Arnold W: Successful treatment of noise-induced cochlear ischemia, hypoxia, and hearing loss. Ann NY Acad Sci 1999, 884:233-248

8. Nakashima T, Naganawa $S$, Sone $M$, Tominaga $M$, Hayashi $H$, Yamamoto H, Liu X, Nuttall AL: Disorders of cochlear blood flow. Brain Res Brain Res Rev 2003, 43:17-28

9. Takahashi T, Kalka C, Masuda H, Chen D, Silver M, Kearney M, Magner M, Isner JM, Asahara T: Ischemia- and cytokine-induced mobilization of bone marrow-derived endothelial progenitor cells for neovascularization. Nat Med 1999, 5:434-438
10. Sanberg PR, Park DH, Kuzmin-Nichols N, Cruz E, Hossne NA, Jr., Buffolo E, Willing AE: Monocyte transplantation for neural and cardiovascular ischemia repair. J Cell Mol Med 2010, 14:553-563

11. Ferrara N, Kerbel RS: Angiogenesis as a therapeutic target. Nature 2005, 438:967-974

12. Hamik A, Wang B, Jain MK: Transcriptional regulators of angiogenesis. Arterioscler Thromb Vasc Biol 2006, 26:1936-1947

13. Halkos ME, Zhao ZQ, Kerendi F, Wang NP, Jiang R, Schmarkey LS, Martin BJ, Quyyumi AA, Few WL, Kin H, Guyton RA, Vinten-Johansen $\mathrm{J}$ : Intravenous infusion of mesenchymal stem cells enhances regional perfusion and improves ventricular function in a porcine model of myocardial infarction. Basic Res Cardiol 2008, 103:525-536

14. Tomita S, Li RK, Weisel RD, Mickle DA, Kim EJ, Sakai T, Jia ZQ: Autologous transplantation of bone marrow cells improves damaged heart function. Circulation 1999, 100:II247-II256

15. Silva GV, Litovsky S, Assad JA, Sousa AL, Martin BJ, Vela D, Coulter SC, Lin J, Ober J, Vaughn WK, Branco RV, Oliveira EM, He R, Geng YJ, Willerson JT, Perin EC: Mesenchymal stem cells differentiate into an endothelial phenotype, enhance vascular density, and improve heart function in a canine chronic ischemia model. Circulation 2005, 111:150-156

16. Yalvac ME, Rizvanov AA, Kilic E, Sahin F, Mukhamedyarov MA, Islamov RR, Palotas A: Potential role of dental stem cells in the cellular therapy of cerebral ischemia. Curr Pharm Des 2009, 15:3908-3916

17. Yu J, Fernandez-Hernando C, Suarez Y, Schleicher M, Hao Z, Wright PL, DiLorenzo A, Kyriakides TR, Sessa WC: Reticulon 4B (Nogo-B) is necessary for macrophage infiltration and tissue repair. Proc Natl Acad Sci USA 2009, 106:17511-17516

18. Yin Y, Zhao X, Fang Y, Yu S, Zhao J, Song M, Huang L: SDF-1alpha involved in mobilization and recruitment of endothelial progenitor cells after arterial injury in mice. Cardiovasc Pathol 2010, 19:218-227

19. Wright DE, Bowman EP, Wagers AJ, Butcher EC, Weissman IL: Hematopoietic stem cells are uniquely selective in their migratory response to chemokines. J Exp Med 2002, 195:1145-1154

20. Hiasa K, Ishibashi M, Ohtani K, Inoue S, Zhao Q, Kitamoto S, Sata M Ichiki T, Takeshita A, Egashira K: Gene transfer of stromal cellderived factor-1alpha enhances ischemic vasculogenesis and angiogenesis via vascular endothelial growth factor/endothelial nitric oxide synthase-related pathway: next-generation chemokine therapy for therapeutic neovascularization. Circulation 2004, 109:2454-2461

21. Li N, Lu X, Zhao X, Xiang FL, Xenocostas A, Karmazyn M, Feng Q: Endothelial nitric oxide synthase promotes bone marrow stromal cell migration to the ischemic myocardium via upregulation of stromal cell-derived factor-1alpha. Stem Cells 2009, 27:961-970

22. Wang Y, Hirose K, Liberman MC: Dynamics of noise-induced cellular injury and repair in the mouse cochlea. J Assoc Res Otolaryngol 2002, 3:248-268

23. Akita $Y$, Otani $H$, Matsuhisa S, Kyoi S, Enoki C, Hattori R, Imamura $H$, Kamihata $H$, Kimura $Y$, Iwasaka T: Exercise-induced activation of cardiac sympathetic nerve triggers cardioprotection via redox-sensitive activation of eNOS and upregulation of iNOS. Am J Physiol Heart Circ Physiol 2007, 292:H2051-H2059

24. Young KC, Torres E, Hatzistergos KE, Hehre D, Suguihara C, Hare JM: Inhibition of the SDF-1/CXCR4 axis attenuates neonatal hypoxiainduced pulmonary hypertension. Circ Res 2009, 104:1293-1301

25. Mudry A, Tange RA: The vascularization of the human cochlea: its historical background. Acta Otolaryngol Suppl 2009, 3-16

26. Shi X, Dai M, Yang Y, Kachelmeier A, Xiu R, Nuttall A: Bone Marrow Cells to Resident Tissue Macrophages in Relation to INOS-Derived Nitric Oxide in the Blood-Labyrinth-Barrier. ARO Abstracts, 2010, 237

27. Shi $X$, Nuttall AL: Upregulated iNOS and oxidative damage to the cochlear stria vascularis due to noise stress. Brain Res 2003, 967:1-10

28. Madlambayan GJ, Butler JM, Hosaka K, Jorgensen M, Fu D, Guthrie SM, Shenoy AK, Brank A, Russell KJ, Otero J, Siemann DW, Scott EW, Cogle CR: Bone marrow stem and progenitor cell contribution to neovasculogenesis is dependent on model system with SDF-1 as a permissive trigger. Blood 2009, 114:4310-4319

29. Tan BT, Lee MM, Ruan R: Bone-marrow-derived cells that home to acoustic deafened cochlea preserved their hematopoietic identity. J Comp Neurol 2008, 509:167-179

30. Hirose K, Discolo CM, Keasler JR, Ransohoff R: Mononuclear phagocytes migrate into the murine cochlea after acoustic trauma. J Comp Neurol 2005, 489:180-194 
31. Moncada S, Palmer RM, Higgs EA: Biosynthesis of nitric oxide from L-arginine: a pathway for the regulation of cell function and communication. Biochem Pharmacol 1989, 38:1709-1715

32. Alderton WK, Cooper CE, Knowles RG: Nitric oxide synthases: structure, function and inhibition. Biochem J 2001, 357:593-615

33. Schgoer W, Theurl M, Jeschke J, Beer AG, Albrecht K, Gander R, Rong S, Vasiljevic D, Egger M, Wolf AM, Frauscher S, Koller B, Tancevski I, Patsch JR, Schratzberger P, Piza-Katzer H, Ritsch A, Bahlmann FH, Fischer-Colbrie R, Wolf D, Kirchmair R: Gene therapy with the angiogenic cytokine secretoneurin induces therapeutic angiogenesis by a nitric oxide-dependent mechanism. Circ Res 2009, 105:994-1002

34. Lee PC, Salyapongse AN, Bragdon GA, Shears LL, 2nd, Watkins SC, Edington HD, Billiar TR: Impaired wound healing and angiogenesis in eNOS-deficient mice. Am J Physiol 1999, 277:H1600-H1608

35. Yamasaki K, Edington HD, McClosky C, Tzeng E, Lizonova A, Kovesdi I, Steed DL, Billiar TR: Reversal of impaired wound repair in iNOS-deficient mice by topical adenoviral-mediated iNOS gene transfer. J Clin Invest 1998, 101:967-971

36. Tornabene SV, Sato K, Pham L, Billings P, Keithley EM: Immune cell recruitment following acoustic trauma. Hear Res 2006, 222:115-124

37. Ichimiya I, Yoshida K, Hirano T, Suzuki M, Mogi G: Significance of spiral ligament fibrocytes with cochlear inflammation. Int J Pediatr Otorhinolaryngol 2000, 56:45-51

38. Fujioka M, Kanzaki S, Okano HJ, Masuda M, Ogawa K, Okano H: Proinflammatory cytokines expression in noise-induced damaged cochlea. J Neurosci Res 2006, 83:575-583

39. Hanisch UK, Kettenmann H: Microglia: active sensor and versatile effector cells in the normal and pathologic brain. Nat Neurosci 2007, 10:1387-1394

40. Block ML, Zecca L, Hong JS: Microglia-mediated neurotoxicity: uncovering the molecular mechanisms. Nat Rev Neurosci 2007, 8:57-69

41. Kigerl KA, Gensel JC, Ankeny DP, Alexander JK, Donnelly DJ, Popovich PG: Identification of two distinct macrophage subsets with divergent effects causing either neurotoxicity or regeneration in the injured mouse spinal cord. J Neurosci 2009, 29:13435-13444

42. Ritter MR, Banin E, Moreno SK, Aguilar E, Dorrell MI, Friedlander M: Myeloid progenitors differentiate into microglia and promote vascular repair in a model of ischemic retinopathy. J Clin Invest 2006, 116: 3266-3276

43. Shi $X$, Ren T, Nuttall AL: Nitric oxide distribution and production in the guinea pig cochlea. Hear Res 2001, 153:23-31

44. Heinrich UR, Selivanova O, Feltens R, Brieger J, Mann W: Endothelial nitric oxide synthase upregulation in the guinea pig organ of Corti after acute noise trauma. Brain Res 2005, 1047:85-96

45. Zhang $\mathrm{Y}$, Wittner $\mathrm{M}$, Bouamar $\mathrm{H}$, Jarrier $\mathrm{P}$, Vainchenker $\mathrm{W}$, Louache $\mathrm{F}$ : Identification of CXCR4 as a new nitric oxide-regulated gene in human CD34+ cells. Stem Cells 2007, 25:211-219

46. Cherla RP, Ganju RK: Stromal cell-derived factor 1 alpha-induced chemotaxis in T cells is mediated by nitric oxide signaling pathways. J Immunol 2001, 166:3067-3074

47. Bonig H, Watts KL, Chang KH, Kiem HP, Papayannopoulou T: Concurrent blockade of alpha4-integrin and CXCR4 in hematopoietic stem/progenitor cell mobilization. Stem Cells 2009, 27:836-837

48. Itoh T, Satou T, Ishida H, Nishida S, Tsubaki M, Hashimoto S, Ito H: The relationship between SDF-1alpha/CXCR4 and neural stem cells appearing in damaged area after traumatic brain injury in rats. Neurol Res 2009, 31:90-102

49. Haider H, Jiang S, Idris NM, Ashraf M: IGF-1-overexpressing mesenchymal stem cells accelerate bone marrow stem cell mobilization via paracrine activation of SDF-1alpha/CXCR4 signaling to promote myocardial repair. Circ Res 2008, 103:1300-1308

50. Swinson DE, Jones JL, Cox G, Richardson D, Harris AL, O'Byrne KJ: Hypoxia-inducible factor-1 alpha in non small cell lung cancer: relation to growth factor, protease and apoptosis pathways. Int $\mathrm{J}$ Cancer 2004, 111:43-50

51. Hong X, Jiang F, Kalkanis SN, Zhang ZG, Zhang XP, DeCarvalho AC, Katakowski M, Bobbitt K, Mikkelsen T, Chopp M: SDF-1 and CXCR4 are up-regulated by VEGF and contribute to glioma cell invasion. Cancer Lett 2006, 236:39-45

52. Saha RN, Pahan K: Regulation of inducible nitric oxide synthase gene in glial cells. Antioxid Redox Signal 2006, 8:929-947

53. Saha RN, Pahan K: Signals for the induction of nitric oxide synthase in astrocytes. Neurochem Int 2006, 49:154-163

54. Vertes D, Axelsson A, Miller J, Liden G: Cochlear vascular and electrophysiological effects in the guinea pig to $4 \mathrm{kHz}$ pure tones of different durations and intensities. Acta Otolaryngol 1981, 92:15-24 